Abstracta Iranica Abstracta Iranica

Revue bibliographique pour le domaine irano-aryen

Volume 26 | 2005

Comptes rendus des publications de 2003

\title{
Comparative Studies of King Darius's Bisitun Inscription. Thesis, Harvard University, 2001, xxiv + 486 p.
}

\section{Rüdiger Schmitt}

\section{Q OpenEdition \\ 12 Journals}

Édition électronique

URL : http://journals.openedition.org/abstractairanica/1475

ISSN : 1961-960X

\section{Éditeur :}

CNRS (UMR 7528 Mondes iraniens et indiens), Éditions de l'IFRI

\section{Édition imprimée}

Date de publication : 15 mai 2005

ISSN : 0240-8910

\section{Référence électronique}

Rüdiger Schmitt, «Comparative Studies of King Darius's Bisitun Inscription. Thesis, Harvard University,

2001, xxiv + 486 p. », Abstracta Iranica [En ligne], Volume $26 \mid 2005$, document 19, mis en ligne le 25 novembre 2005, consulté le 25 septembre 2020. URL : http://journals.openedition.org/

abstractairanica/1475

Ce document a été généré automatiquement le 25 septembre 2020.

Tous droits réservés 


\title{
Comparative Studies of King Darius's Bisitun Inscription. Thesis, Harvard University, 2001, xxiv +486 p.
}

\author{
Rüdiger Schmitt
}

1 The principal aim of the author of this dissertation supervised by the Assyriologist John Huehnergard, is to establish a stemma of all the known versions of the famous great and of the minor inscriptions of King Darius I. For this he examined 1. DB and DBa-k in Old Persian, 2. DB (including $§ 70$ or "DBl") and DBb-k in Elamite, 3. DB and DBb-j in Babylonian, 4. the two fragments BE 3627 and Bab. 41446 of the Babylonian version found in Babylon, 5. the copy of the Aramaic version found in Elephantine, and 6. the short Aramaic fragment found in Saqqara and first identified as Bīsutūn-like by Wesselius, BiOr 41, 1984, 443. In the first major part of the book (ch. IV, pp. 73-236), all these versions and fragments, arranged by way of short paragraphs, are presented in transliteration, transcription, and translation; the texts are in principle updated versions of the available editions by Schmitt (OPers.), Grillot-Susini et al. (Elam.), von Voigtlander (Bab.), and Porten-Yardeni (Aram.). Sometimes these editions are followed all too closely, whereas in other cases the author is able to propose new readings on the basis of new photographs taken by him. A second major part (ch. V, pp. 237-391) contains comparative lexicons of the four languages (with grammatical notes), so that one can see at a glance, e.g., that the counterparts of OPers. pas: Elam. meni, Bab. arki, and Aram. 'hr. From these entries, one then sees that Elam. meni also renders OPers. ava $[1] \bar{a}$ and avada "then", that for Bab. arki we find the same, but also OPers. aparam "afterwards", and so forth, and always with all references given for the language of the particular lemma. All in all, the book is thus an important tool for further work on the Bīsutūn texts, even if it must not be used without appropriate caution.

2 As to the literary stemma developed by the author on the basis of the similarities and dissimilarities among the versions (additions or omissions of words, phrases or even paragraphs), contrary to the common opinion he assumes the existence of two Vorlagen 
(the German word being used here), one (A) for the three texts carved at Mt. Bīsutūn and a second one $(B)$ for the other texts, i.e. the Aramaic papyri and the fragments found in Babylon. This latter Vorlage B must have been an abbreviated version of DB, the one sent "everywhere into the countries" (DB IV 92). According to the author, we have to start from an oral old Persian text dictated by King Darius, which was written down phonetically in Aramaic letters (like the Naqš-i Rustam inscription in Aramaic script). It is on this description of the revolts only that are based the 'edited' texts with their expansions in the introducing and the concluding sections: both the Elamite and the Babylonian version, but also the Old Persian text engraved in cuneiform characters, which is arranged, however, in a slightly different way and moreover shows some minor additional changes. The Vorlage $B$ is an Aramaic translation made at the same time as the old Persian Vorlage $A$ and "intended to be a diplomatic dispatch to the provinces" (p. 49). The very complex, but grosso modo quite plausible literary stemma of all the DB versions is presented graphically on pp. 56-57 in a figure which chiefly leaves one point open, viz. the way the casualty statistics regarded as one of the innovations of the Vorlage B all of sudden found their way into the Babylonian Bīsutūn version.

INDEX

Thèmes : 2.1. Langues anciennes

Mots-clés : linguistique, lexiques comparatifs, vieux perse, papyrus araméenne, manuscrit araméen, Babylonien

Keywords : linguistics, inscriptions, élamite, comparative lexicons, Old Persian, Aramaic papyri, Aramaic script, Elamite, Babylonian

nompropre Bisotun = Bīsutūn, Naqsh-e Rostam = Naqš-i Rustam, Darius

\section{AUTEURS}

\section{RÜDIGER SCHMITT}

Laboe 